\title{
Kajian Terhadap Keberadaan dan Pendanaan Rintisan Sekolah Bertaraf Internasional (RSBI)
}

\author{
Hendarman \\ email: hendarman@kemdiknas.go.id, Balitbang Kemdiknas
}

\begin{abstract}
Abstrak: Penyelenggaraan satuan pendidikan menuju bertaraf internasional telah dimulai sejak tahun 2006, yaitu melalui pendirian dan penyelenggaraan Rintisan Sekolah Bertaraf Internasional (RSBI). Berbagai gugatan, pandangan dan kritik yang bersifat pro-kontra dari berbagai lapisan masyarakat terhadap penyelenggaraan RSBI muncul sejalan dengan implementasinya. Hal yang signifikan yaitu usulan untuk memberhentikan penyelenggaraan RSBI dan sistem pendanaan yang memberatkan orang tua peserta didik. Tulisan ini merupakan kajian secara yuridis terhadap keberadaan RSBI serta pendanaan yang seyogianya diberlakukan dalam penyelenggaraannya. Kajian secara yuridis menunjukkan bahwa menghentikan penyelenggaraan RSBI tidak dimungkinkan sepanjang peraturan perundang-undangan yang berlaku belum diubah. Terkait pendanaan terhadap RSBI, memang terjadi perbedaan tafsir dari peraturan perundang-undangan yang berlaku sehingga terjadi pungutan-pungutan yang membebankan orang tua peserta didik. Implikasi dari hal-hal tersebut bahwa keberlanjutan RSBI harus diikuti dengan adanya evaluasi dengan menggunakan indikator-indikator kunci yang dapat memutuskan kemungkinan promosi RSBI menjadi SBI atau penurunan status menjadi sekolah regular; dan penetapan sistem keuangan di tingkat satuan pendidikan RSBI secara transparan dan akuntabel yang dapat menjelaskan berapa yang diterima dan dipergunakan dari Pemerintah, pemerintah daerah, dan masyarakat termasuk orang tua peserta didik.
\end{abstract}

Kata kunci: RSBI, pendanaan, dan standar internasional

\begin{abstract}
The execution of a unit having international standards of education has been commenced since 2006 through the establishment of the so-called "rintisan sekolah bertaraf internasional" (RSBI). Pros and cons were addressed for the implementation of RSBI. The significant one is to terminate this initiative due to the burden funding implications that parents are to take care. This paper analyses the existence of RSBI and funding mechanism which are supposed to be in place from the view of legal aspect. The analysis shows that the appeal to terminate RSBI will not be possible unless there is an amendment to the existing laws and regulations. In terms of budget allocation for RSBI, the analysis shows that misinterpretations towards the regulation bring about the big-fees taken from parents. It is recommended that RSBI is to be continued but with such an evaluation using a number of key-indicators to decide for the promotion and the depromotion of RSBI to be SBI (international standard schools) or back to regular schools; and to set up a transparent and accountable finance system in the school which could indicate in detail the receiving and spending of money received from central office, local authority and society including students' parents.
\end{abstract}

Key words: RSBI, finance, and international standar

\section{Pendahuluan}

Orang tua di berbagai daerah dipusingkan dengan semakin sulitnya mencari sekolah berkualitas dan semakin mahalnya biaya sekolah (Harian Kompas, 6 Juli 2011). Meskipun sudah ada dana yang dikucurkan Pemerintah untuk setiap satuan pendidikan, kenyataannya hal tersebut tidak mengurangi pungutan yang dilakukan sekolah terhadap orang tua siswa. Kesulitan utama peserta didik dan orang tua terutama karena sebagian sekolah publik yang berkualitas sudah berubah status menjadi RSBI. Sekolah berstatus RSBI tersebut cenderung bebas memungut biaya masuk dari orang tua peserta didik, namun belum ada mekanisme pelaporan penggunaan yang transparan terhadap dana yang diperoleh. RSBI tetap saja melakukan pungutan yang cenderung besar walaupun sudah mendapat berbagai 
sumber dana, di antaranya dari Pemerintah dan pemerintah daerah. Di lain pihak, orang tua maupun pihak terkait mengalami kesulitan untuk memperoleh klarifikasi mengenai peruntukan dari dana tersebut.

Terungkap pula bahwa di beberapa kota seperti Cirebon, Bandung dan Jakarta dimana biaya negeri masuk SMP negeri bersatus RSBI minimal Rp 6 juta. Adapun untuk SMA negeri berstatus RSBI, biaya masuk dapat di atas Rp 15 juta (Harian Kompas, 6 Juli 2011). Pungutan di kota Cirebon tersebut misalnya terjadi di SMP Negeri 1 Cirebon yang berstatus RSBI, dimana orang tua dipungut sumbangan Rp 6 juta dan uang SPP Rp 485.000 per bulan. Tanggapan dari panitia penerimaan di sekolah tersebut adalah bahwa sumbangan berdasarkan kesepakatan orang tua dan komite sekolah, yang mana dana tersebut digunakan untuk kepentingan peserta didik seperti pembangunan laboratorium, dan berbagai fasilitas kelas (Harian Kompas, 8 Juli 2011). Namun, di sisi lain bahwa sekolah-sekolah di Surabaya, Jawa Timur termasuk yang berstatus RSBI, bebas biaya masuk sekolah. Wali murid hanya dibebani uang seragam yang bervariasi Rp500.000 Rp650.000 per siswa.

Kritikan lain terkait RSBI adalah mekanisme penerimaan peserta didik baru PPDB). Ditengarai bahwa rekrutmen peserta didik baru masih kurang transparan terutama dalam proses seleksi dan kriteria yang digunakan. Kriteria seleksi tidak jelas terkait dengan beberapa indikasi di antaranya kemampuan orang tua dalam membayar cenderung lebih dijadikan pertimbangan utama dibandingkan capaian akademik siswa. Sementara itu latar belakang ekonomi orangtua peserta didik belum dijadikan kriteria utama walaupun peserta didik yang bersangkutan memiliki potensi secara akademik. Menurut Jumono dari Aliansi Orang tua Peduli Pendidikan, dengan besarnya pungutan masuk RSBI tersebut maka anak-anak cerdas dari keluarga miskin tidak mungkin bisa masuk sekolah RSBI. Dikemukakannya lebih lanjut, bahwa terkesan omong kosong dengan situasi pungutan yang ada bahwa RSBI menyediakan kuota 20 persen untuk siswa miskin (Harian Kompas, 6 Juli 2011). Di sisi lain, sebagaimana muncul di berbagai media, RSBI menyebabkan daya tampung sekolah menurun karena jumlah siswa per kelas dibatasi, maksimal 30 orang. Padahal sekolah regular dapat menampung 40 peserta didik per kelas.

Pemerintah telah mengembangkan dan menyelenggarakan program pendidikan yang diarahkan mencapai Standar Bertaraf Internasional (SBI). Penyelenggaraan program pendidikan ini dimulai pada tahun 2006 melalui pendirian sejumlah rintisan sekolah bertaraf internasional (RSBI). RSBI sendiri adalah sekolahsekolah yang telah mencapai standar nasional atau SSN (Sekolah Standar Nasional). Standar Nasional dimaksud adalah menurut Peraturan Pemerintah Republik Indonesia Nomor 19 Tahun 2005 tentang Standar Nasional Pendidikan yang memiliki lingkup yaitu: a) standar isi, b) standar proses, c) standar kompetensi luusan, d) standar pendidik dan tenaga kependidikan, e) standar sarana dan prasarana, f) standar pengelolaan, g) standar pembiayaan, dan h) standar penilaian pendidikan.

Secara prinsip, sekolah-sekolah di Indonesia dapat dikategorisasikan dengan merujuk pada SPM (Standar Pelayanan Minimal) dan Sekolah Standar Nasional (SSN). Pada kenyataannya, persentase terbesar adalah sekolah-sekolah yang belum dan bahkan baru mencapai status SPM. Misalnya, untuk satuan pendidikan Sekolah Dasar, jumlah sekolah belum mencapai status SPM mencapai hampir setengah dari total SD yaitu 44.84\%; yang sudah berkategori SPM adalah $51.71 \%$. sedangkan yang mencapai SSN (Sekolah Standar Nasional) baru 3.29\%. Jumlah SD RSBI adalah sebanyak 239 sekolah dari total SD sebanyak 146.904 sekolah, atau baru mencapai $0.16 \%$. Tabel 1 menunjukkan kategori dan jumlah dari sekolah-sekolah yang berada di jenjang pendidikan dasar dan menengah. Secara keseluruhan, status sekolah di Indonesia sebenarnya baru mencapai SPM atau di bawah status tersebut dimana persentasenya mencapai $89.20 \%$ dari jumlah total sekolah sebesar 201.557 sekolah.

Sampai akhir tahun 2010, jumlah RSBI yang ada di seluruh Indonesia yaitu $0.65 \%$ dari total jumlah satuan pendidikan dari pendidikan dasar hingga pendidikan menengah. Rekapitulasi data sekolah dengan statusnya dapat dilihat pada Tabel 1. 
Tabel 1. Rekapitulasi Data Sekolah berdasarkan Kategori Sekolah

\begin{tabular}{|l|r|l|r|l|r|r|r|r|r|r|r|}
\hline & \multicolumn{2}{|c|}{ SSM } & \multicolumn{2}{c|}{ SPM } & \multicolumn{2}{c|}{ SSN } & \multicolumn{2}{c|}{ RSBI } & \multicolumn{2}{c|}{ SBI } & Total \\
\hline & Jumlah & $\%$ & Jumlah & $\%$ & Jumlah & $\%$ & Jumlah & $\%$ & Jumlah & $\%$ & Jumlah \\
\hline SD & 65.869 & 44,84 & 75.965 & 51,71 & 4.831 & 3,29 & 239 & 0,16 & 0 & 0 & 146.904 \\
\hline SMP & 8.892 & 26,01 & 15.226 & 44,54 & 9.711 & 28,41 & 356 & 1,04 & 0 & 0 & 34.185 \\
\hline SMA & 3.990 & 35,30 & 4.210 & 37,24 & 2.745 & 24,28 & 359 & 3,18 & 0 & 0 & 11.304 \\
\hline SMK & 2.493 & 27,20 & 3.143 & 34,30 & 3.177 & 34,67 & 351 & 3,83 & 0 & 0 & 9.164 \\
\hline Total & 81.244 & 40,31 & 98.544 & 48,89 & 20.464 & 10,15 & 1.305 & 0,65 & 0 & 0 & 201.557 \\
\hline
\end{tabular}

Sumber: Penjelasan Mendiknas pada Raker Kemdiknas dengan DPR tanggal 21 Maret 2011

Tabel 1 tersebut menunjukkan bahwa jumlah rintisan sekolah bertaraf internasional (RSBI) cenderung masih dalam persentase kecil yaitu $0.65 \%$. Tabel dimaksud sekaligus menegaskan bahwa hingga saat ini belum ada satupun sekolah di Indonesia yang dikategorikan sebagai Sekolah Bertaraf Internasional (SBI).

Dari berbagai kondisi obyektif yang ada tersebut, muncul usulan dari masyarakat agar RSBI atau yang sejenis segera dihentikan. Alasan utama pengusulan utama penghentian penyelenggaraan RSBI yaitu: 1) tidak menjamin prinsip keadilan terhadap peserta didik yang orang tuanya tidak mampu secara ekonomi; dan 2) besarnya pungutan yang dibebankan kepada orang tua.

Tulisan ini pada hakikatnya merupakan kajian untuk menanggapi isu-isu yang menyang-kut keberadaan dan pendanaan dari rintisan sekolah bertaraf internasional (RSBI). Kajian ini akan mencermati dengan mempertimbangkan berbagai aspek untuk menjawab pertanyaan pokok berikut, yaitu: 1) apakah rintisan sekolah bertaraf internasional memiliki dasar hukum yang jelas untuk dapat berjalan dan diimplementasikan?; dan 2) apakah pendanaan yang terjadi pada implementasi rintisan sekolah bertaraf internasional (RSBI) selama ini didukung oleh peraturan perundang-undangan yang jelas?

\section{Kajian Literatur Keberadaan RSBI ditinjau dari Landasan Yuridis}

Penyelenggaraan rintisan sekolah bertaraf internasional (RSBI) sesungguhnya merujuk kepada amanah berbagai peraturan perundangundangan yang berlaku. Peraturan perundangundangan tersebut meliputi antara lain UndangUndang Nomor 20 Tahun 2003 tentang Sistem
Pendidikan Nasional (UUSPN), Peraturan Pemerintah Nomor 19 Tahun 2005 tentang Standar Nasional Pendidikan, Peraturan Pemerintah Nomor 38 Tahun 2007 tentang Pembagian Urusan Pemerintahan antara Pemerintah, Pemerintahan Daerah Provinsi, dan Pemerintahan Daerah Kabupaten/Kota, Peraturan Pemerintah Nomor 17 Tahun 2010 tentang Pengelolaan dan Penyelenggaraan Pendidikan, Peraturan Pemerintah Nomor 48 Tahun 2008 tentang Pendanaan Pendidikan.

Beberapa rujukan legal yang dapat memperkuat aspek legalitas status atau keberadaan dari penyelenggaraan rintisan sekolah bertaraf internasional, sebagai berikut: 1) Pasal 50 ayat (3) UUSPN yang menyatakan bahwa "Pemerintah dan/atau Pemerintah Daerah menyelenggarakan sekurang-kurangnya satu satuan pendidikan pada semua jenjang pendidikan untuk dikembangkan menjadi satuan pendidikan yang bertaraf internasional" (Departemen Pendidikan Nasional, Republik Indonesia, 2006a). Apabila diperhatikan penjelasan dari UUSPN maka untuk pasal tersebut dikatakan "cukup jelas"; 2) Pasal 143 Peraturan Pemerintah Nomor 17 Tahun 2010 tentang Pengelolaan dan Penyelenggaraan Pendidikan menyatakan "Satuan pendidikan bertaraf internasional merupakan satu pendidikan yang telah memenuhi Standar Nasional Pendidikan dan diperkaya dengan standar pendidikan di negara maju (Kementerian Pendidikan Nasional, 2010); 3) Peraturan Pemerintah Nomor 17 Tahun 2010 mempertegas khususnya pada BAB VIII "Satuan Pendidikan Bertaraf Internasional" dimulai dari pasal 143 sampai dengan pasal 154. Terkait dengan satuan pendidikan dasar, pasal 144 ayat (1) menyatakan "Pemerintah kabupaten/kota menyelenggarakan paling sedikit 1 (satu) SD bertaraf internasional dan/atau memfasilitasi 
penyelenggaraan paling sedikit 1 (satu) SD bertaraf internasional yang diselenggarakan masyarakat. Selanjutnya ayat (2) menyatakan bahwa "dalam hal ketentuan sebagaimana dimaksud pada ayat (1) tidak dapat dipenuhi, maka pemerintah kabupaten/kota menyelenggarakan paling sedikit 1 (satu) SD yang dikembangkan menjadi satuan pendidikan bertaraf internasional. Ayat (6) dalam pasal yang sama menyatakan "Pemerintah kabupaten/kota membantu dan memfasilitasi penyelenggaraan SD bertaraf internasional atau rintisan bertaraf internasional yang diselenggarakan oleh masyarakat sebagaimana dimaksud pada ayat (1)". Peran pemerintah provinsi dijelaskan dalam pasal 145 ayat (1) yaitu "Pemerintah provinsi memfasilitasi dan membantu penyelenggaraan SD bertaraf internasional di kabupaten/kota di wilayahnya"; Terkait SMP, SMA, dan SMK maka pasal 146 ayat (1), 4) menyatakan "Pemerintah provinsi menyelenggarakan paling sedikit 1 (satu) SMP, 1 (satu) SMA, dan 1 (satu) SMK bertaraf internasional dan/atau memfasilitasi penyelenggaraan paling sedikit 1 (satu) SMP, 1 (satu) SMA, dan 1 (satu) SMK bertaraf internasional yang diselenggarakan masyarakat di setiap kabupaten/kota di wilayahnya. Pasal yang sama ayat (2) menyatakan bahwa "dalam hal ketentuan sebagaimana dimaksud pada ayat (1) belum dapat dipenuhi, pemerintah provinsi menyelenggarakan paling sedikit 1 (satu) SMP, 1 (satu) SMA, dan 1 (satu) SMK yang dikembangkan menjadi satuan pendidikan bertaraf internasional. Sedangkan ayat (3) pasal ini menyatakan "Penyelenggaraan rintisan pendidikan bertaraf internasional sebagaimana dimaksud pada ayat (2) dapat dilaksanakan secara parsial menurut rombongan belajar atau mata pelajaran. Peran kabupaten/kota dicantumkan dalam ayat (6) yaitu "Pemerintah kabupaten/kota dapat membantu penyelenggaraan SMP, SMA, dan SMK bertaraf internasional atau yang dikembangkan menjadi satuan pendidikan bertaraf internasional"; dan 5) Pengembangan untuk menjadi standar bertaraf internasional dari masing-masing satuan pendidikan tersebut juga telah diatur tersendiri. Untuk SD, diatur dalam Pasal 144 ayat (5) PP No 17 tahun 2010 yaitu "pengembangan SD menjadi satuan pendidikan bertaraf internasional dilaksanakan paling lama 7 (tujuh) tahun".
Sedangkan untuk SMP, SMA, dan SMK diatur dalam Pasal 146 ayat (5) yaitu "pengembangan SMP, SMA, dan SMK menjadi satuan pendidikan bertaraf internasional dilaksanakan paling lama 6 (enam) tahun.

Dari kajian berbagai peraturan perundangundangan yang berlaku, keberadaan rintisan sekolah bertaraf internasional (RSBI) sah secara hukum. Pengubahan ataupun penghapusan terhadap kebijakan atau implementasi RSBI sebagaimana yang seringkali dilontarkan harus dilakukan dengan mengubah peraturan perundang-undangan yang mengaturnya.

Penghentian RSBI mungkin saja dapat dilakukan dengan mempertimbangkan waktu pelaksanaannya. Misalnya, dimungkinkan bahwa SD RSBI yang ada untuk dihentikan atau diubah menjadi sekolah regular apabila setelah 7 (tujuh) tahun tidak dapat meningkatkan kinerja yang layak sebagai Sekolah Bertaraf Internasional (SBI) atau bahkan kemudian tidak juga layak sebagai RSBI. Permasalahannya adalah bahwa sampai ini belum ada satu indikator pun yang telah disusun untuk menentukan layak tidaknya suatu sekolah dengan status RSBI untuk dipromosikan sebagai SBI (Sekolah Bertaraf Internasional) atau kemudian kehilangan statusnya dan kembali sebagai sekolah regular atau Sekolah Standar Nasional (SSN).

Yang sesungguhnya perlu ditinjau lebih lanjut adalah proses bagaimana suatu satuan pendidikan memperoleh persetujuan dan ketetapan secara hukum menjadi rintisan sekolah bertaraf internasional (RSBI). Berbagai kritikan dan kecaman dari masyarakat terhadap kelayakan RSBI dapat diduga berasal dari proses pengusulannya. Secara sederhana dapat dijelaskan yaitu dengan mengaitkan kepada Pasal 143 Peraturan Pemerintah Nomor 17 Tahun 2010 tentang Pengelolaan dan Penyelenggaraan Pendidikan yang menyatakan "Satuan pendidikan bertaraf internasional merupakan satu pendidikan yang telah memenuhi Standar Nasional Pendidikan dan diperkaya dengan standar pendidikan di negara maju (Kementerian Pendidikan Nasional, 2010). Apakah betul seluruh RSBI yang ada sudah memenuhi standar nasional pendidikan (SNP)?

Misalnya, untuk standar proses dimana standar telah ditetapkan dalam Pasal 19 ayat (1) 
pada PP Nomor 19 tahun 2005 tentang Standar Nasional Pendidikan, yaitu "... diselenggarakan secara interaktif, inspiratif, menyenangkan, menantang, memotivasi peserta didik untuk berpartisipasi aktif, serta memberikan ruang lingkup bagi prakarsa, kreativitas, dan kemandirian sesuai dengan bakat, minat, dan perkembangan fisik serta psikologis peserta didik" (Departemen Pendidikan Nasional, Republik Indonesia, 2006b). Apakah proses pembelajaran seluruh RSBI yang sudah ada sekarang minimal sudah mengikuti standar tersebut? Tafsiran untuk RSBI yaitu seyogianya satuan pendidikan berstatus RSBI mempunyai standar proses atau standar pembelajaran lebih dari yang tertulis dalam Pasal 19 ayat (1) tersebut.

Dalam konteks pendidik dan tenaga kependidikan, PP Nomor 19 Tahun 2005 memberikan standar yang jelas. Di antaranya dalam Pasal 29 ayat (2) terkait dengan pendidik pada SD/MI atau bentuk lain yang sederajat, memiliki: (a) kualifikasi akademik pendidikan minimum diploma empat (DIV) atau sarjana (S1); (b) latar belakang pendidikan tinggi di bidang pendidikan SD/MI, kependidikan lain, atau psikologi; dan (c) sertifikat profesi guru untuk SD/MI. sedangkan pendidik pada SMP/MTs serta SMA/MA atau bentuk lain yang sederajat memiliki: (a) kualifikasi akademik pendidikan minimum diploma empat (D-IV) atau sarjana (S1); (b) latar belakang pendidikan tinggi dengan program pendidikan yang sesuai dengan mata pelajaran yang diajarkan; dan (c) sertifikat profesi guru untuk SMP/MTs \{Pasal 29 ayat (3) dan ayat (4)\}. Pertanyaan mendasar yang harus dikaji lebih cermat adalah apakah satuan pendidikan berstatus RSBI sebelum ditetapkan secara hukum sebagai RSBI sudah memenuhi pendidik dan tenaga kependidikan sesuai dengan kriteria dimaksud?

Apabila RSBI yang ada ternyata pada saat pemrosesan awal belum memenuhi standar nasional pendidikan maka hal inilah yang secara potensial menimbulkan berbagai penyimpangan terhadap operasionalisasi RSBI. Selanjutnya, apabila memang terjadi penyimpangan dalam proses pengusulan tersebut, perlu dicermati faktor-faktor yang menyebabkan. Misalnya, apakah keluarnya keputusan penetapan satuan pendidikan di kabupaten/kota karena semata- mata mengakomodasikan keinginan atau aspirasi daerah yang cenderung menuntut kemungkinan tersebut karena penafisran klausul yang ada yaitu "Pemerintah dan/atau Pemerintah Daerah menyelenggarakan sekurang-kurangnya satu satuan pendidikan pada semua jenjang pendidikan untuk dikembangkan menjadi satuan pendidikan yang bertaraf internasional"? Apabila memang itu yang terjadi, dapat dipahami bahwa RSBI yang ada belum memunculkan mutu capaian pembelajaran yang baik, di samping juga munculnya berbagai pungutan.

\section{Pendanaan RSBI ditinjau dari Landasan Yuridis dan Empiris}

Peraturan Pemerintah Nomor 48 Tahun 2008 tentang Pendanaan Pendidikan telah juga mengatur pendanaan terkait penyelenggaraan rintisan sekolah bertaraf internasional (Departemen Pendidikan Nasional, 2008). Pasalpasal yang mengatur pendanaan pendidikan bertaraf internasional atau yang sedang dikembangkan menuju bertaraf internasional yang diselenggarakan oleh Pemerintah atau pemerintah daerah adalah: Pasal 9, Pasal 13, Pasal 20, dan Pasal 24. Pada hakekatnya peran Pemerintah terhadap tanggung jawab pendanan dilaksanakan sampai dengan terpenuhinya Standar Nasional Pendidikan.

Beberapa kajian terkait pendanaan pendidikan termasuk yang terkait dengan RSBI yaitu: 1) Tanggungjawab pendidikan diatur dalam Pasal 2 ayat (1) dan ayat (2). Ayat (1) menyatakan "Pendanaan pendidikan menjadi tanggung jawab bersama antara Pemerintah, pemerintah daerah, dan masyarakat". Sesuai dengan ayat (2) pasal yang sama, masyarakat meliputi (a) penyelenggara atau satuan pendidika yang didirikan masyarakat, (b) peserta didik, orang tua atau wali peserta didik, dan (3) pihak lain selain yang dimaksud dalam huruf a dan huruf b yang mempunyai perhatian dan peranan dalam bidang pendidikan; 2) Biaya pendidikan meliputi biaya satuan pendidikan, biaya penyelenggaraan dan/ atau pengelolaan pendidikan, dan biaya pribadi peserta didik, diatur dalam Pasal 3 ayat (1) PP Nomor 48 tahun 2008. Sedangkan biaya satuan pendidikan terdiri atas (a) biaya investasi yang terdiri atas biaya investasi lahan pendidikan, dan 
biaya investasi selain lahan pendidikan; (b) biaya operasi yang terdiri atas biaya personalia dan biaya nonpersonalia; (c) bantuan biaya pendidikan, dan (d) beasiswa; 3) Adapun sumber pendanaan tambahan yang diperlukan untuk pemenuhan rencana pengembangan satuan atau program pendidikan yang diselenggarakan Pemerintah menjadi bertaraf internasional dan/ atau berbasis keunggulan lokal baik untuk biaya investasi lahan \{Pasal 9 ayat (1)\}, biaya investasi selain lahan $\{$ Pasal 13 ayat (1)\}, biaya personalia \{Pasal 20 ayat (1)\}, biaya nonpersonalia \{Pasal 24 ayat (1\} dapat berasal dari: Pemerintah, pemerintah daerah, masyarakat, bantuan pihak asing yang tidak mengikat; dan/atau sumber lain yang sah; 4) Adapun sumber pendanaan tambahan yang diperlukan untuk pemenuhan rencana pengembangan satuan atau program pendidikan yang diselenggarakan pemerintah daerah sesuai kewenangannya menjadi bertaraf internasional dan/atau berbasis keunggulan lokal baik untuk biaya investasi lahan \{Pasal 9 ayat (2)\}, biaya investasi selain lahan \{Pasal 13 ayat (2)\}, biaya personalia \{Pasal 20 ayat (2)\}, biaya nonpersonalia \{Pasal 24 ayat (2\} dapat berasal dari Pemerintah, pemerintah daerah, masyarakat, bantuan pihak asing yang tidak mengikat; dan/ atau sumber lain yang sah; 5) Anggaran biaya investasi lahan satuan pendidikan \{Pasal 9 ayat (3)\}, biaya investasi selain lahan \{Pasal 13 ayat (3)\}, biaya personalia \{Pasal 20 ayat (3)\}, biaya nonpersonalia $\{$ Pasal 24 ayat (3)\} untuk satuan pendidikan yang dikembangkan menjadi bertaraf internasional dan/atau berbasis keunggulan lokal harus merupakan bagian integral dari anggaran tahunan satuan pendidikan yang diturunkan dari rencana kerja tahunan yang merupakan pelaksanaan dari rencana strategis satuan pendidikan.

Sesuai dengan Peraturan Pemerintah Nomor 48 Tahun 2008 tentang Pendanaan Pendidikan, sumber-sumber pendanaan pendidikan untuk RSBI, seyogianya berasal dari Pemerintah (APBN), pemerintah daerah (APBD) dan masyarakat. Dalam konteks ini, Pemerintah melalui Kementerian Pendidikan Nasional telah menunjukkan komitmen sesuai dengan aturan tersebut. Komitmen tersebut diwujudkan dalam bentuk pemberian hibah (block-grant) kepada satuan sekolah yang berstatus RSBI.
Besarnya hibah yang diberikan untuk SD-RSBI bervariasi antara Rp 100 juta hingga Rp 500 juta per-sekolah bergantung pada tahun pembukaan program RSBI dan tahapan yang berlaku untuk SD bersangkutan. Hibah untuk SMP-RSBI besarnya sama untuk semua sekolah, yaitu Rp. 400 juta pada tahun 2007, dan Rp. 300 juta per sekolah untuk tahun 2008-2010. Untuk SMA-RSBI, besarnya hibah adalah Rp 300 juta per sekolah untuk tahun 2006-2008; dan mulai tahun 2009, besarnya bervariasi berdasarkan kinerja yaitu antara Rp 100 juta hingga Rp 500 juta. Adapun besarnya hibah untuk SMK-RSBI sebesar Rp 450 juta per sekolah pada tahun 2007, sebesar Rp 250 juta pada tahun 2008, dan sebesar Rp 100 juta pada tahun 2010. Khusus untuk SMK-RSBI, pemberian hibah pada tahun 2006 dibagi dua tahap: 1) SMK RSBI yg berdiri tahap I mendapatkan Rp 200 juta dan 2) SMK-RSBI yang berdiri tahap II mendapatkan Rp 500 juta. Pada tahun 2009, besarnya hibah yang diberikan di SMK-RSBI bervariasi berdasarkan jumlah siswa di masingmasing sekolah.

Data tentang kontribusi masing-masing pemerintah daerah kabupaten/kota tampaknya belum tersedia secara lengkap hingga saat ini. Di samping itu data dimaksud cenderung tidak mudah untuk diperoleh dari pemerintah daerah maupun dari masing-masing satuan pendidikan yang berstatus RSBI. Data tersebut sesungguhnya sangat diperlukan khususnya dalam menentukan rumusan berapa yang seyogianya dimintakan dari masyarakat yaitu pihak orang tua untuk operasionalisasi RSBI di masing-masing satuan pendidikan. Beberapa pengamatan dan hasil wawancara dengan berbagai pihak di satuan pendidikan, terungkap bahwa tidak sedikit pemerintah daerah yang tidak mengalokasikan anggaran dalam APBD untuk keperluan satuan pendidikan yang berstatus RSBI di wilayahnya.

Diduga bahwa akhirnya hal inilah yang menjadi salah satu alasan bagi satuan pendidikan yang berstatus RSBI untuk melakukan pungutan terhadap orang tua peserta didik. Di sisi lain, kemungkinan satuan pendidikan untuk berani melakukan pungutan karena aspek legal yang tercantum dalam Peraturan Menteri Pendidikan Nasional Nomor 78 Tahun 2009 tentang "Penyelenggaraan Sekolah Bertaraf Internasional 
dalam Jenjang Pendidikan Dasar dan Menengah" (Kementerian Pendidikan Nasional, 2009). Pasal 16 dari Pemendiknas ini mengatur tentang persyaratan penerimaan siswa baru pada sekolah. Salah satu dari persyaratan adalah pasal 16 ayat (1) a.5, b.6, dan c.8 yang berbunyi: "Kesediaan membayar pungutan untuk menutupi kekurangan biaya diatas standar pembiayaan pendidikan kecuali bagi peserta didik dari orang tua yang tidak mampu secara ekonomi." Pernyataan "kesediaan membayar pungutan ...." tersebut yang diduga dijadikan acuan dari satuan pendidikan terhadap berbagai pungutan yang dilakukan.

Menarik untuk menermati temuan studi yang dilakukan oleh Pusat Penelitian Kebijakan dan Inovasi Pendidikan yang memperkuat kebenaran adanya pungutan tersebut dalam bentuk sumbangan pembangunan (Pusat Penelitian Kebijakan dan Inovasi Pendidikan, 2010). Studi tersebut dilakukan di 130 sekolah yang terdiri dari SD, SMP, SMA, dan SMK. Pada satuan pendidikan Sekolah Dasar, sumbangan pembangunan berkisar antara Rp 100 ribu hingga maksimum Rp 7,7 juta dengan rata-rata Rp. 1,5 juta. Untuk SMP, sumbangan pembangunan berkisar antara Rp.250 ribu hingga maksimum Rp 15 juta dengan ratarata Rp 2,23 juta. Sedangkan sumbangan pembangunan di SMA berkisar antara Rp 135 ribu hingga maksimum Rp 10 juta dengan rata-rata Rp 2,7 juta. Sementara di SMK, sumbangan pembangunan berkisar antara Rp. 125 ribu hingga maksimum Rp 3,8 juta dengan rata-rata Rp 1,28 juta.

Yang menjadi permasalahan dalam konteks pungutan selama ini adalah bahwa orang tua peserta didik maupun pihak masyarakat pada umumnya tidak dapat mengakses peruntukan dan penggunaan dari pungutan dimaksud. Padahal pasal 52 PP Nomor 48 tahun 2008 tentang Pendanaan Pendidikan mensyaratkan ketentuanketentuan yang wajib dipenuhi terhadap pungutan oleh satuan pendidikan. Ketentuan dimaksud di antaranya bahwa a) pungutan didasarkan pada perencanaan investasi dan/atau operasi yang jelas dan dituangkan dalam rencana strategis, rencana kerja tahunan, serta anggaran tahunan yang mengacu pada Standar Nasional Pendidikan, b) perencanaan investasi dan/atau operasi tersebut diumumkan secara transparan kepada pemangku kepentingan satuan pendidikan, c) dana yang diperoleh disimpan dalam rekening atas nama satuan pendidikan, d) dana yang diperoleh dibukukan secara khusus oleh satuan pendidikan terpisah dari dana yang diterima dari penyelenggara satuan pendidikan, dan e) tidak dikaitkan dengan persyaratan akademik untuk penerimaan peserta didik, penilaian hasil belajar peserta didik, dan/atau kelulusan peserta didik dari satuan pendidikan.

Terkait penggunaan pungutan tersebut, temuan dari Pusat Penelitian Kebijakan dan Inovasi Pendidikan menunjukkan bahwa: a) sebagian besar penggunaan dana dimanfaatkan untuk sarana dan prasarana ( $S D=45 \%$; $\mathrm{SMP}=38 \%$; SMA $=47 \%$; dan $\mathrm{SMK}=54 \%$ ); b) alokasi untuk PBM berkisar antara 9\%-18\%; dan c) kegiatan siswa lainnya berkisar antara 4\%-10\% (Pusat Penelitian Kebijakan dan Inovasi Pendidikan, 2010). Memperhatikan temuan tersebut, sekali lagi patut dipertanyakan kondisi awal dari satuan-satuan pendidikan yang berstatus RSBI yaitu apakah memang sudah memenuhi standar nasional pendidikan termasuk standar sarana dan prasarana, ataukah penunjukan satuan pendidikan tersebut cenderung "dipaksakan" dalam rangka memungkinkan masing-masing kabupaten/kota memiliki satuan pendidikan yang akan dikembangkan menjadi bertaraf internasional. Dengan kata lain, patut dipertanyakan dan dievaluasi kembali proses pengajuan dan pengusulan suatu satuan pendidikan untuk menjadi RSBI.

\section{Metodologi}

Dalam melakukan kajian terhadap kedua pertanyaan pokok sebagaimana dimaksud di bagian pendahuluan, sumber-sumber data yang digunakan terdiri atas peraturan perundangundangan yang berlaku khususnya yang terkait dengan rintisan sekolah bertaraf internasional (RSBI), fakta empiris yang ada termasuk dari berbagai pernyataan atau ulasan yang diungkapkan dalam media tertulis termasuk surat kabar, dan hasil-hasil penelitian yang terkait. Peraturan perundang-undangan yang dimaksud termasuk Undang-Undang Nomor 20 Tahun 2003 tentang Sistem Pendidikan Nasional (UUSPN), Peraturan 
Pemerintah Nomor 19 Tahun 2005 tentang Standar Nasional Pendidikan, Peraturan Pemerintah Nomor 38 Tahun 2007 tentang Pembagian Urusan Pemerintahan antara Pemerintah, Pemerintahan Daerah Provinsi, dan Pemerintahan Daerah Kabupaten/Kota, Peraturan Pemerintah Nomor 17 Tahun 2010 tentang Pengelolaan dan Penyelenggaraan Pendidikan, dan Peraturan Pemerintah Nomor 48 Tahun 2008 tentang Pendanaan Pendidikan.

Analisis yang dilakukan adalah meta-analysis terhadap sumber data dan informasi sebagaimana dimaksudkan sebelumnya. Dalam melakukan analisis, setiap isu yang menjadi fokus akan dirujuk kepada apa yang tercantum dalam peraturan perundang-undangan. Selanjutnya dilakukan proses menafsirkan ketentuan dimaksud yang dihubungkan dengan fakta-fakta yang ada. Fakta dimaksud merupakan pernyataan atau penjelasan dari berbagai pemangku kepentingan baik dari pihak yang mendukung maupun yang tidak menyetujui keberadaan dan pendanaan RSBI.

Asumsi yang digunakan dalam kajian ini adalah bahwa data dan informasi yang tertulis dalam media tertulis merupakan informasi yang dapat dipertanggungjawabkan dengan mempertimbangkan aspek legalitas dari keberadaan Undang-Undang Nomor 14 Tahun 2008 tentang Keterbukaan Informasi Publik (KIP). Analisa atau kajian yang dilakukan akan merujuk kepada: (1) keberadaan RSBI ditinjau dari landasan yuridis, dan (2) pendanaan RSBI ditinjau dari landasan yuridis dan empiris.

\section{Simpulan dan Saran \\ Simpulan}

Mengacu pada uraian dan pembasasan di atas, dapat disimpulkan sebagai berikut. Pertama, penyelenggaraan rintisan sekolah bertaraf internasional yang sudah ada selama ini, masih dapat tetap dilanjutkan mengingat berbagai peraturan perundang-undangan yang berlaku secara jelas memperkuat keberadaan satuansatuan pendidikan berstatus RSBI tersebut. Kedua, status sejumlah satuan pendidikan berstatus RSBI yang menimbulkan berbagai penyimpangan dalam penyelenggaraannya, diduga disebabkan dari proses penunjukan dan penetapannya secara hukum bermula yang tidak merujuk pada ketentuan-ketentuan yang berlaku. Diduga bahwa sejumlah RSBI yang ada sesungguhnya belum memenuhi standar nasional pendidikan akibat aspirasi kabupaten/kota yang menginginkan daerahnya memiliki satuan pendidikan dengan menunjuk peraturan perundang-undangan yang menyatakan bahwa "Pemerintah dan/atau Pemerintah Daerah menyelenggarakan sekurang-kurangnya satu satuan pendidikan pada semua jenjang pendidikan untuk dikembangkan menjadi satuan pendidikan yang bertaraf internasional". Ketiga, pendanaan RSBI merupakan tanggung jawab bersama Pemerintah, Pemerintah Daerah dan masyarakat. Namun demikian, setelah terbentuknya RSBI secara hukum, terdapat pihak-pihak yang tidak menunjukkan komitmen untuk turut berkontribusi dalam penyelenggaraan RSBI yaitu khususnya pihak pemerintah daerah. Hal tersebut ditunjukkan oleh fakta bahwa belum semua daerah mengalokasikan anggaran untuk RSBI yang berada di wilayahnya dalam APBD mereka. Keempat, pungutan yang dibebankan terhadap orang tua peserta didik dengan besar yang bervariasi disebabkan oleh berbagai faktor, di antaranya karena: a) pemerintah daerah tidak atau belum mengalokasikan anggaran khusus bagi RSBI dalam APBD; b) belum atau tidak ada aturan yang mengatur besaran sumbangan atau pungutan dari orang tua peserta didik; dan c) tidak atau belum adanya sistem pengawasan dari berbagai pihak terhadap pungutan yang menyebabkan tidak bersifat transparan dan akuntabel dalam hal peruntukannya.

\section{Saran}

Atas dasar simpulan, disarankan agar: 1) Keberadaan satuan pendidikan berstatus RSBI seyogianya segera dievaluasi dengan menggunakan indikator-indikator yang relevan. Hasil evaluasi dimaksud akan menentukan status satuan pendidikan dimaksud yaitu kemungkinan untuk dapat dipromosikan sebagai Sekolah Bertaraf Internasional, atau tetap sebagai Rintisan Sekolah Bertaraf Internasional, atau bahkan diturunkan status sebagai sekolah regular. Indikator-indikator tersebut di antaranya dapat diukur dari a) jumlah peserta didik dari satuan pendidikan yang lebih 
rendah (SD) dapat masuk ke satuana pendidikan yang lebih tinggi (SMP, atau dari SMP ke SMA/SMK) yang berstatus RSBI; atau b) lulusan SMA RSBI yang dapat diterima pada perguruan-perguruan tinggi baik di dalam maupun di luar negeri yang berperingkat internasional; 2) Proses penetapan terhadap keputusan menetapkan RSBI yang sudah ada perlu ditinjau kembali kebenarannya dalam arti apakah proses tedahulu sudah memenuhi persyaratan sesuai dengan peraturan perundang-undangan yang berlaku. Dengan demikian, apabila dari data yang ada ditemukan bahwa pada saat pengusulan terdahulu status satuan pendidikan tersebut belum memenuhi standar nasional pendidikan atau kategori SSN (Sekolah Standar Nasional), perlu dilakukan pencabutan status RSBI dari satuan pendidikan dimaksud; 3) Legalitas pungutan dan besarnya perlu dikaji kembali dengan mempertimbangkan berbagai peraturan perundang-undangan serta kebijakan yang telah diambil oleh Pemerintah selama ini. Sehubungan dengan hal tersebut, kemampuan atau kesediaan membayar tidak dijadikan sebagai persyaratan sebagai telah ditemukan pada Peraturan Menteri Pendidikan Nasional Nomor 78 tahun 2009 yaitu kesediaan membayar tersebut dijadikan sebagai salah satu kriteria penerimaan peserta didik baru. Adanya pencatuman kriteria tersebut dalam peraturan dimaksud diduga menyebabkan satuan-satuan pendidikan mengambil kebijakan untuk melakukan pemungutan terhadap peserta didik. Dengan demikian, satuan-satuan pendidikan berstatus RSBI harus memiliki sistem pelaporan secara transparan tentang penerimaan dan penggunaan pendanaan pendidikan yang bersumber dari pihak Pemerintah, pemerintah daerah dan masyarakat, yang dapat diakses oleh orangtua siswa dalam rangka menjamin transparansi dan akuntabilitas pengelolaan anggaran RSBI di tingkat satuan pendidikan; dan 4) Pertimbangan agar satuan pendidikan pada jenjang pendidikan dasar yang diselenggarakan pemerintah tidak memungut biaya dari peserta didik. Sebagai implikasi, Pemerintah bersama-sama dengan Pemerintah Provinsi dan Pemerintah Kabupaten/Kota menanggung biaya penyelenggaraan pada jenjang pendidikan dasar yang diselenggarakan oleh pemerintah. Sementara itu, pada jenjang pendidikan menengah masih dimungkinkan untuk memungut biaya pendidikan untuk menutupi kekurangan biaya di atas standar pembiayaan, yang didasarkan pada RPS/RKS dan RKAS dan dengan mempertimbangkan kemampuan ekonomi orang tua siswa.

\section{Pustaka Acuan}

Departemen Pendidikan Nasional. 2008. Peraturan Pemerintah Republik Indonesia Nomor 48 Tahun 2008 tentang Pendanaan Pendidikan, Jakarta: Departemen Pendidikan Nasional.

Departemen Pendidikan Nasional, Republik Indonesia. 2006a. Undang-Undang Republik Indonesia Nomor 20 Tahun 2003 tentang Sistem Pendidikan Nasional. Jakarta: Departemen Pendidikan Nasional.

Departemen Pendidikan Nasional, Republik Indonesia. 2006b. Peraturan Pemerintah Republik Indonesia Nomor 19 Tahun 2005 tentang Standar Nasional Pendidikan. Jakarta: Departemen Pendidikan Nasional.

Harian Kompas. 2011. "Sekolah Semakin Sulit dan Mahal: RSBI Hanya Dinikmati Siswa Kaya". Kompas, 6 Juli 2011, halaman 1.

Harian Kompas. 2011. "Pungutan Dikeluhkan: Dibentuk Tim Investigasi di Sulawesi Selatan". Kompas, 8 Juli 2011, halaman 12 kolom 2-4.

Kementerian Pendidikan Nasional. 2011. Penjelasan Mendiknas pada Raker Kemdiknas dengan DPR tanggal 21 Maret 2011. Jakarta: Sekretariat Jenderal

Kementerian Pendidikan Nasional. 2010. Peraturan Pemerintah Republik Indonesia Nomor 17 Tahun 2010 tentang Pengelolaan dan Penyelenggaraan Pendidikan. Jakarta: Kementerian Pendidikan Nasional.

Kementerian Pendidikan Nasional. 2009. Peraturan Menteri Pendidikan Nasional Nomor 78 Tahun 2009 tentang Penyelenggaraan Sekolah Bertaraf Internasional pada Jenjang Pendidikan Dasar dan 
Menengah. Jakarta: Kementerian Pendidikan Nasional

Kementerian Dalam Negeri. 2007. Peraturan Pemerintah Nomor 38 Tahun 2007 tentang Pembagian Urusan Pemerintahan antara Pemerintah, Pemerintahan Daerah Provinsi, dan Pemerintahan Daerah Kabupaten/Kota,Jakarta: Kementerian Dalam Negeri.

Pusat Penelitian Kebijakan, Badan Penelitian dan Pengembangan, Kementerian Pendidikan Nasional. 2010. Evaluasi terhadap Penyelenggaraan RSBI di SD, SMP, SMA, dan SMK (laporan dalam proses). Jakarta: Pusat Penelitian Kebijakan. 